Diabetologia $9,197-202(1973)$

(C) by Springer-Verlag 1973

\title{
Weight Regain after Low Calorie Diet: Long Term Pattern of Blood Sugar, Serum Lipids, Ketone Bodies and Serum Insulin Levels*
}

\author{
R. Hewing, H. Liebermeister, H. Daweke, F.A. Gries, D. Grüneklee \\ Second Medical Clinic of the University Düsseldorf and Diabetes Research Institute at the University Düsseldorf, \\ Germany (F.R.G.)
}

Received: December 7, 1972, accepted, January 2, 1973

Summary. 4 years after controlled elinical treatment with a 1000 calorie mixed diet, 24 patients were reinvestigated to assess (1) whether the improved metabolism, as observed during therapy, is merely the result of starvation and (2) to what extent this improvement continues beyond the time of dietary treatment. - The following tests were carried out: Oral G.T.T. $(100 \mathrm{~g})$, immunoreactive insulin, free fatty acids, free glycerol, triglycerides, cholesterol, acetoacetate and beta-hydroxybutyrate. - 12 patients had been able to maintain their weight or reduce further. They showed a slightly improved glucose tolerance and a more normal secretion kinetic for insulin release. However, 12 individuals who were found to have a $35 \%$ weight gain (Broca), returning almost to their initial weight, showed a decreased glucose tolerance compared with previous examination, while insulin levels were slightly elevated, with a typically delayed secretion. Both groups showed a weight-independent elevation of cholesterol and triglyceride levels and a marked decline of plasma FFA, free glycerol and ketone bodies. The parameters of lipid metabolism may possibly be influene. ed by the composition of the diet, while a change of weight after reduction primarily affects blood sugar levels and, to a lesser extent, insulin levels.

Key words: Obesity, glucose tolerance, weight reduction, long-term prognosis.
Previous investigations of metabolic activity during weight reduction have been limited to the time of dietary treatment, leaving unanswered the question of maintained therapeutic effect following this period. Furthermore, it could not be ascertained whether an improved metabolism in obese subjects was the result of slight hunger or weight reduction. For this reason we have carried out comparative follow-up studies in patients we reported on earlier [27].

\section{Patients and methods of investigations}

In our obesity clinic 37 out-patients with constant weight were investigated [27], 4 years after the controlled clinical treatment they were requested to reattend. One patient had died in the meantime, 3 patients refused reexamination and 13 did not reply to our letter. 4 patients of the present group $(n=24)$ had also been examined previously, but were not recorded in the preceding publication.

The patients were requested not to alter their eating habits on the day prior to the examination; metabolic changes due to illness, medication or fasting were excluded on questioning. The weight was determined as on initial examination. According to previous investigations, the following tests were performed fasting:

1. $(100 \mathrm{~g})$ - glucose tolerance test (o.GTT), [41].

2. Free fatty acids (FFA), [9, 30].

3. Free glycerol $[23]$.

4. Triglycerides [24].

5. Total cholesterol.

6. Acetoacetate (AcAc), [44]

* We are grateful to the "Deutsche Forschungsgemeinschaft" and the "Landesamt für Forschung, Nordrhein-Westfalen" for grants which made this work possible.
7. Beta-Hydroxybutyrate (HBS), [44].

8. Immunoreactive insulin (IRI), [17].

Intravenous glucose tolerance tests and measurements of insulin-like activity with the fat pad and muscle assay were not carried out.

The results obtained in 24 patients at the initial investigation were compared with those of follow-up studies. They are given as the mean value with standard error of the mean $(\vec{x} \pm S E M)$. The number of investiga. tions is given in brackets. The statistics of paired com. parison were made with the aid of Wileoxon's test [45].

The patients who successfully kept their weight during the years after treatment $(n=8)$ or were able to reduce further $(n=4)$ were compared with those who gained more than $10 \%$ of the normal weight aceording to Broca $(n=12)$. The analysis of eating habits revealed that only 5 patients adhered to a strict diet consisting of 1500 calories daily, 8 patients had a calorie intake of about 2000,9 reported a moderate reduction of food intake, 2 ate according to their appetite.

\section{Results}

\section{Change of weight}

Table 1 shows that most patients were women with at least $30 \%$ overweight, according to Broca (average $+69 \pm 6 \%$ ), before treatment. After the overweight had been reduced by half $(+38 \%)$, an $11 \%$ weight regain (Broca) had resulted within 4 years after the dietary regime was terminated. Half of the patients of that group had maintained their weight or reduced further. The fact that the mean overweight decreased, in spite of the weight remaining stable, is due to growth of the younger patients. Five individuals reached their initial weight, only two exceeded it again. 
Patients with subclinical diabetes $(n=12)$ showed a mean weight loss of $22.1 \mathrm{~kg}$; metabolically healthy subjects $(n=12)$ a loss of $16.2 \mathrm{~kg}$. The last group showed a subsequent weight gain of $7.0 \mathrm{~kg}$, those patients with impaired carbohydrate metabolism had a mean weight gain of $9.8 \mathrm{~kg}$.
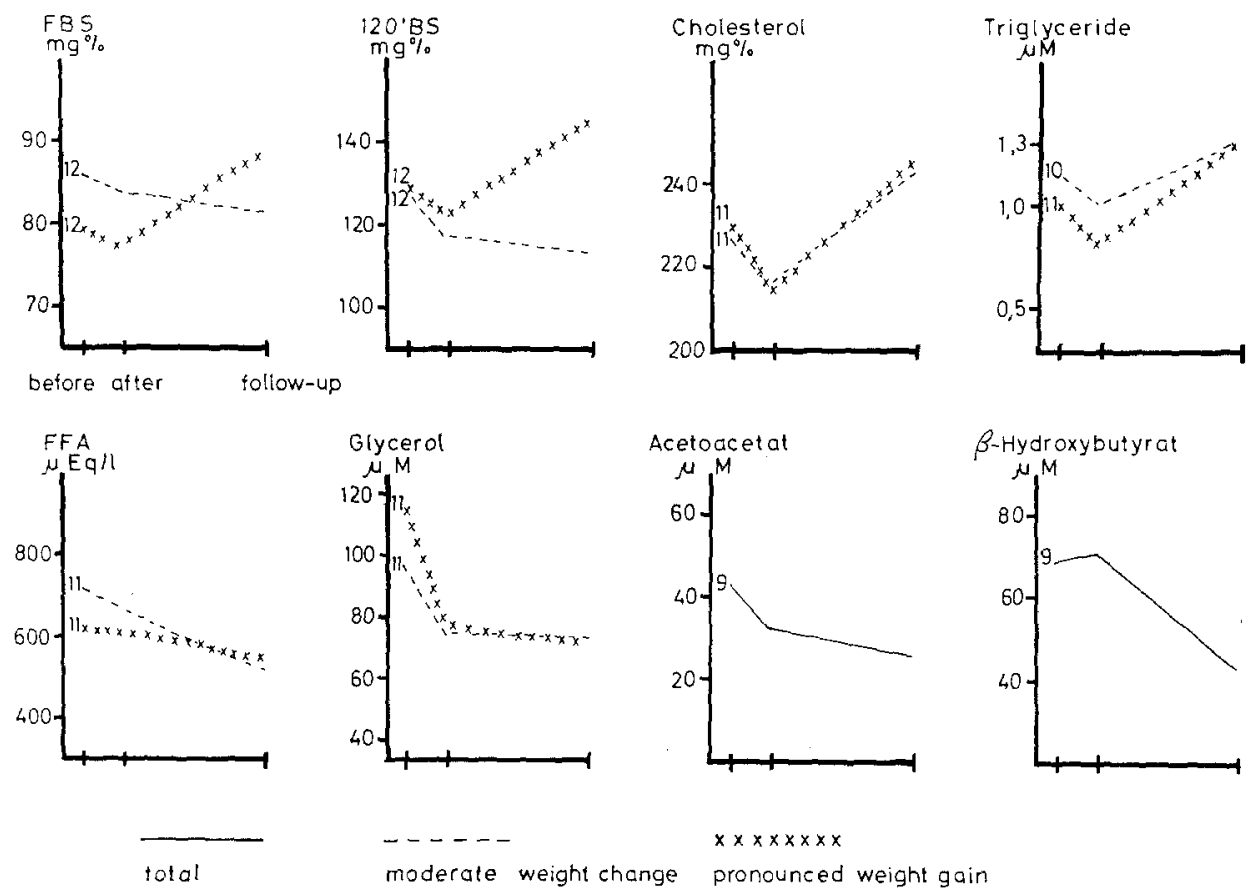

$x \times \times \times x \times x \times$

pronounced weight gain

Fig. 1. Blood sugar and lipid metabolites before and after weight reduction as well as on follow-up examination of the subgroups with moderate weight change and pronounced weight gain after dietary therapy

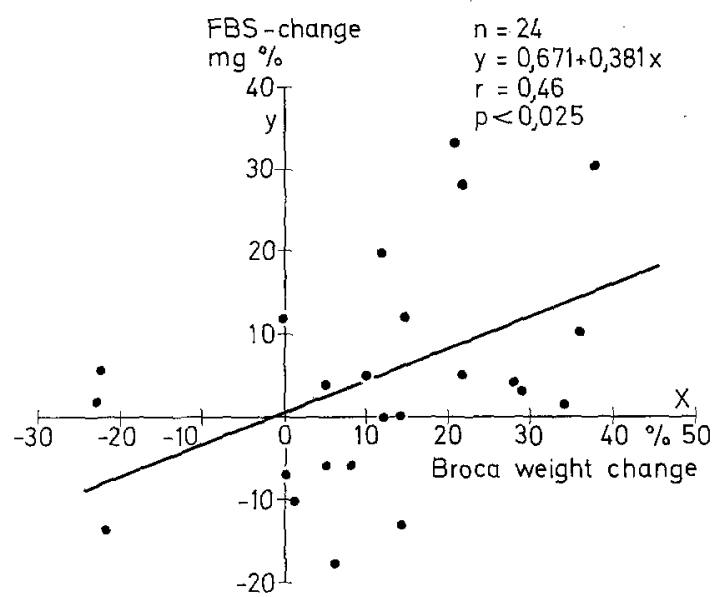

Fig. 2. Correlation of weight change and alteration of fasting blood sugar after dietary therapy

\section{Glucose tolerance}

The group regaining weight showed a marked deterioration of carbohydrate tolerance as compared with the previous investigations (Table 2, Fig. 1). All blood sugar levels after $100 \mathrm{~g}$ glucose p.o. were clearly

\section{Influence on fat metabolism}

a) Free fatty acids and free glycerol in fasting serum (Table 2, Fig. 1): FFA concentrations changed only slightly with the reducing diet; a definite elevation of FFA, as evident in periods of fasting, was not observed. Both groups showed a subsequent significant decrease with a return to normal values. At the same time, both groups showed a decline of plasma glycerol although normal results had not quite been reached.

b) Cholesterol and triglycerides in fasting serum (Table 2, Fig. 1): Cholesterol as well as triglyceride levels, which had shown a slight decline during treat ment, increased significantly. Since both groups were affected, the increase appears to be weight-independent.

c) Ketone bodies in fasting serum (Fig. 1): Ketone bodies during reducing therapy were only observed in 9 persons and a slight decrease was noted which continued further. On account of the small number of patients, a subdivision according to weight change was not made.

\section{Influence on serum insulin results}

For better comparison, the insulin values obtained at the present investigation were measured together 
with serum samples previously obtained during the weight reduction period. The results obtained on the latter samples were found to be similar to those reported earlier [27]. In response to a glucose load, there was a typical elevation of insulin levels with delayed to the normal pattern. Maximal values were observed at $60 \mathrm{~min}$ followed by a definite drop after two hours. However, in patients who had regained weight, there remained a delayed maximum and moderate decrease, typically seen in obesity.

Table 1. Clinical data of the groups before and after dietary therapy as well as on

\begin{tabular}{|c|c|c|c|}
\hline & Total & $\begin{array}{l}\text { Moderate weight } \\
\text { change }\end{array}$ & $\begin{array}{l}\text { Pronounced } \\
\text { weight gain }\end{array}$ \\
\hline Number & 24 & 12 & 12 \\
\hline Females & 18 & 11 & 7 \\
\hline Age (years) & $47.3(21-68)^{\mathrm{a}}$ & $46.4(21-68)$ & $48.1(31-67)$ \\
\hline Years after reduction & $4.1(2.3-5.4)$ & $3.8(2.3-5.4)$ & $4.4(3.2-5.2)$ \\
\hline \multicolumn{4}{|l|}{ Overweight } \\
\hline $\begin{array}{l}\text { before weight } \\
\text { reduction }\end{array}$ & $+69 \pm 6^{b}$ & $+68 \pm 10$ & $+70 \pm 8$ \\
\hline $\begin{array}{l}\text { after weight } \\
\text { reduction }\end{array}$ & $+38 \pm 5$ & $+43 \pm 8$ & $+33 \pm 7$ \\
\hline follow-up & $+49 \pm 6$ & $+41 \pm 9$ & $+58 \pm 6$ \\
\hline \multicolumn{4}{|l|}{ Weight (kg) } \\
\hline $\begin{array}{l}\text { before weight } \\
\text { reduction }\end{array}$ & $103 \pm 4$ & $108 \pm 0$ & $98 \pm 6$ \\
\hline $\begin{array}{l}\text { after weight } \\
\text { reduction }\end{array}$ & $84 \pm 4$ & $92 \pm 5$ & $76 \pm 5$ \\
\hline follow-up & $92 \pm 3$ & $92 \pm 5$ & $92 \pm 5$ \\
\hline
\end{tabular}

a Range in brackets b Mean ( $\mathrm{x} \pm \mathrm{SEM})$.

Table 2. Blood glucose, serum insulin (IRI) and lipid metabolites before and after weight reduction as well as on follow-up examination. Means $\pm S E M$, number of assays in brackets

\begin{tabular}{|c|c|c|c|c|c|c|c|c|}
\hline \multirow[t]{2}{*}{$\begin{array}{l}\text { assay } \\
\text { (range of controls) }^{d}\end{array}$} & \multicolumn{2}{|c|}{$\begin{array}{l}\text { subjects with } \\
\text { moderate weight change }\end{array}$} & \multirow[b]{2}{*}{ followup } & \multirow[b]{2}{*}{$p^{c}$} & \multicolumn{2}{|c|}{$\begin{array}{l}\text { subjects with } \\
\text { pronounced weight gain }\end{array}$} & \multirow[b]{2}{*}{ followup } & \multirow[b]{2}{*}{$p^{\mathrm{c}}$} \\
\hline & before & after & & & before & after & & \\
\hline $\begin{array}{l}\text { Bloodsugar }{ }^{\mathrm{a}} \\
(74 \pm 2 \mathrm{mg} \%)\end{array}$ & $\begin{array}{l}86 \pm 3 \\
(12)\end{array}$ & $\begin{array}{l}84 \pm 2 \\
(12)\end{array}$ & $\begin{array}{l}81 \pm 3 \\
(12)\end{array}$ & & $\begin{array}{l}80 \pm 4 \\
(12)\end{array}$ & $\begin{array}{r}77 \pm 3 \\
(12)\end{array}$ & $\frac{89 \pm 4}{(12)}$ & $\begin{array}{l}* \\
* *\end{array}$ \\
\hline $\begin{array}{l}120^{\prime} \text { Blood-b sugar } \\
(100 \pm 3 \mathrm{mg} \%)\end{array}$ & $\begin{array}{l}130 \pm 9 \\
(12)\end{array}$ & $\begin{array}{l}118 \pm 6 \\
(12)\end{array}$ & $\begin{array}{l}114 \pm 10 \\
(12)\end{array}$ & & $\begin{array}{l}130 \pm 9 \\
(12\end{array}$ & $\begin{array}{l}123 \pm 5 \\
(12)\end{array}$ & $\begin{array}{l}145 \pm 14 \\
(12)\end{array}$ & $*$ \\
\hline $\begin{array}{l}\mathrm{TRI}^{\mathrm{a}} \\
(26 \pm 8 \mathrm{U} / \mathrm{ml}) \\
120^{\prime} \mathrm{IRI}^{\mathrm{b}} \\
(58 \pm 10 \mathrm{U} / \mathrm{ml})\end{array}$ & $\begin{array}{l}30 \pm 11 \\
(11) \\
70 \pm 17 \\
(9)\end{array}$ & $\begin{array}{c}16 \pm 4 \\
(11) \\
93 \pm 26 \\
(9)\end{array}$ & $\begin{array}{l}12 \pm 4 \\
(10) \\
79 \pm 19 \\
(9)\end{array}$ & & $\begin{array}{l}23 \pm 6 \\
(11) \\
111 \pm 16 \\
(11)\end{array}$ & $\begin{array}{l}15 \pm 2 \\
(11) \\
72 \pm 13 \\
(11)\end{array}$ & $\begin{array}{c}18 \pm 4 \\
(11) \\
89 \pm 17 \\
(10)\end{array}$ & \\
\hline $\begin{array}{l}\mathrm{FFA}^{\mathrm{a}} \\
(551 \pm 60 \text { moles } / 1)\end{array}$ & $\begin{array}{l}715 \pm 45 \\
(11)\end{array}$ & $\begin{array}{l}663 \pm 44 \\
(11)\end{array}$ & $\begin{array}{l}519 \pm 15 \\
\frac{1}{(10)}\end{array}$ & $\begin{array}{l}* * * \\
* *\end{array}$ & $\begin{array}{l}619 \pm 30 \\
(11)\end{array}$ & $\begin{array}{l}611 \pm 41 \\
(11)\end{array}$ & $\begin{array}{l}543 \pm 22 \\
(11)\end{array}$ & $* *$ \\
\hline $\begin{array}{l}\text { Glycerola } \\
(52 \pm 9.4 \text { moles } 1) \\
\text { Cholesterola } \\
(196 \pm 14 \mathrm{mg} \%)\end{array}$ & $\begin{array}{l}97 \pm 11 \\
(11) \\
227 \pm 16 \\
(11)\end{array}$ & $\begin{array}{l}76 \pm 11 \\
(11) \\
216 \pm 15 \\
(11)\end{array}$ & $\begin{array}{l}74 \pm 12 \\
(11) \\
243 \pm 19 \\
(11)\end{array}$ & & $\begin{array}{l}116 \pm 12 \\
(11) \\
231 \pm 15 \\
(11)\end{array}$ & $\begin{array}{l}77 \pm 10 \\
(11) \\
215 \pm 8 \\
(11)\end{array}$ & $\begin{array}{l}72 \pm 6 \\
(12) \\
245 \pm 11 \\
\underset{(12)}{(12)}\end{array}$ & $* * *$ \\
\hline $\begin{array}{l}\text { Triglycerides }{ }^{\mathrm{a}} \\
(0.65 \pm 0.15 \text { mmoles } / 1)\end{array}$ & $\begin{array}{l}1.16 \pm 0.1 \\
(9)\end{array}$ & $\begin{array}{l}1.00 \pm 0.2 \\
(10)\end{array}$ & $\begin{array}{l}1.35 \pm 0.2 \\
(11)\end{array}$ & $* *$ & $\begin{array}{l}1.04 \pm 0.1 \\
(9)\end{array}$ & $\begin{array}{l}0.82 \pm 0.1 \\
(11)\end{array}$ & 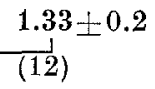 & $* * *$ \\
\hline $\begin{array}{l}\text { number of patients } \\
\text { with impaired GTT }\end{array}$ & $\tilde{5}$ & 1 & 3 & & 7 & 3 & 9 & \\
\hline
\end{tabular}

a Basal values b After $100 \mathrm{~g}$ of glucose by mouth

c Significances of paired comparison: $*=p<0.05, * *=p<0.02$, *** $=p<0.01$

d According to [27]

and enhanced secretion, as well as reduced decline after 3 h, (Table 2, Fig. 3).

At the end of therapy, the sub-group with slight weight change showed a slightly increased insulin secretion after glucose and a secretion kinetic similar

\section{Discussion}

The beneficial effects of weight reduction on the parameters of carbohydrate and fat metabolism have been well documented $[3,5,12,14,15,18,19,20,21$, 
27, 35]. However, Grodsky in particular has pointed out that long-term follow-up studies on metabolic changes after cessation of reducing therapy are sparse $[18,29,31]$. The weight change of our follow-up patients was consistent with that found by other investigators [25, 43], namely a small number of patients returned to or exceeded their initial weight while half of them maintained their weight loss or even reduced further. weight remained lowered while only 4 subjects of this group slightly exceeded their original weight. The group with more or less constant weight showed a further slight reduction of blood sugar following glucose load. This finding may be interpreted as indicating that improvement in carbohydrate tolerance, as seen during the course of dietary measures, is not merely the effect of low caloric nutrition but also the result of reduced body weight. This hypothesis is
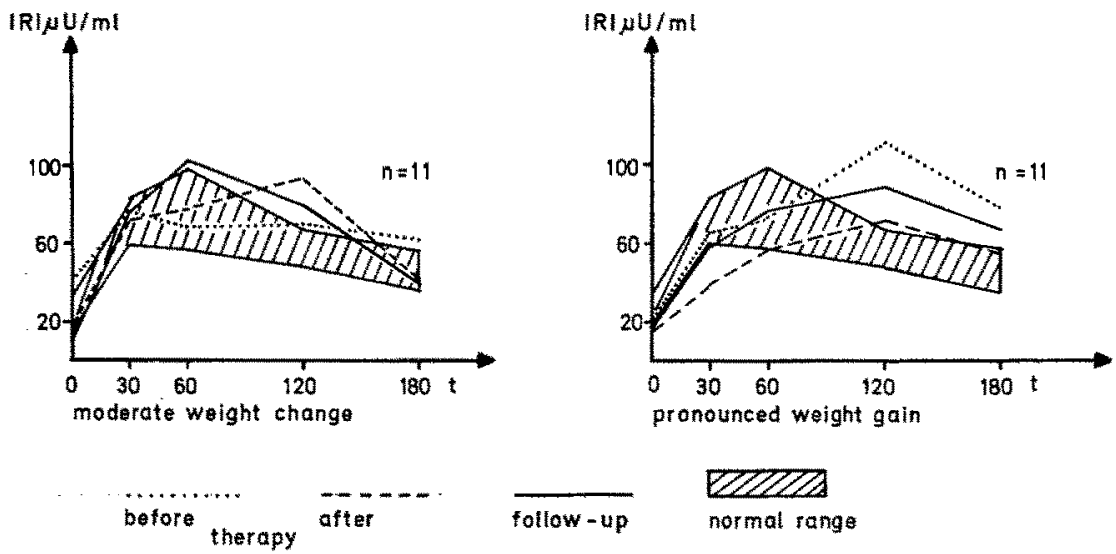

Fig. 3. Serum insulin after $100 \mathrm{~g}$ glucose p.o. before and after weight reduction as well as on follow-up examination of the subgroups with moderate weight change and with weight gain after dietary therapy

Psychological investigations of obese persons $[1,43]$ have shown that those subjects who lost weight rapidly during therapy, i.e. who were particularly cooperative, are less able to resist infuences in their environment leading to obesity and therefore show a greater tendency to increase subsequently in weight. This fact is confirmed by the present results. While the group with severe obesity showed a reduction of $22 \mathrm{~kg}$ during therapy, which is far above that of the other group with a weight loss of $16 \mathrm{~kg}$ (Table 1), it gained subsequently much more weight $(+16 \mathrm{~kg})$ than the other group $( \pm 0 \mathrm{~kg})$.

It is also interesting that weight changes appear to be related to carbohydrate tolerance. While experiments with low calorie diets and appetite suppressors [26] have shown a tendency for overt diabetics to react less favourable to treatment than non-diabetics, the present investigations showed patients with impairment of glucose tolerance to have a mean weight loss of $22.1 \mathrm{~kg}$ as compared with metabolically healthy individuals who had lost $16.2 \mathrm{~kg}$. This is possibly dependent on a stronger motivation. Similarly, the beneficial role of motivation in dietary treatment has been observed in pilots [22].

\section{Carbohydrate metabolism}

Follow-up tests showed that in the group with a marked gain in weight blood sugar during the oral G.T.T. clearly exceeded the levels at the beginning of the study. This result is remarkable, since mean body further supported by the fact that the number of subclinical diabetics in the group of patients with weight regain increased from 3 to 9 , thus being higher than before dietary therapy, while the other group showed no significant change. It is therefore also unlikely that the significant deterioration of glucose tolerance in the group regaining weight is a consequence of the subjects now being 4 years older [4].

For the total group a significant correlation $(r=$ $0.46, p<0.025$ ) ean be established between long-term weight change and alteration of fasting blood sugar, as we described previously in diabetics [28].

These findings support the long-term effect of "relative body weight" upon glucose metabolism indicating that partial regain of body weight can induce marked deterioration.

\section{Lipids}

A clear difference between the sub-groups, as observed for glucose tolerance, could not be demonstrated with triglycerides and cholesterol. During the follow-up period the results increased beyond the initial value in both groups; however, the elevation was only statisti. cally significant in the sub-group with weight regain. It remains questionable as to what extent the increase in age [39] and the quantitative and qualitative change of food, which proved difficult to record, may have influenced these results. Ohlson stated that weight reduction lowers lipids only temporarily [33]. 


\section{Free fatty acids, free glycerol and ketone bodies}

The decrease of fasting levels of free fatty acids and of free glycerol continued in both groups, but in the group with weight regain there was a diminished effect. Ketone bodies could only be determined in some patients; consequently, only a small number could be followed up and this prevented further subdivision. The ketone bodies as well as the serum concentration of glycerol and free fatty acids decreased further in the total group. These four parameters, which most likely reflect the actual metabolic situation at the time of the blood test, as compared with the slower reacting blood sugar, triglyceride and cholesterol concentrations, were not influenced by the gradual change of weight. The nutrition prior to testing appears to be a decisive factor. The behaviour of the ketone bodies shows that the latent state of hunger at the end of the reducing period was no longer present at the time of follow-up examination.

\section{Serum insulin}

With the determination of insulin levels certain difficulties were encountered. It is known from publications by Powers et al. [34] that extended storage of serum leads to altered insulin-like activity results. In addition, repeated thawing or freezing may interfere with the determination. In spite of these implications, we felt that IRI determinations on serum obtained before the follow-up study should be repeated. In general the quoted results in Fig. 3 and Table 2 do not differ much from the original estimations.

Summarizing, it may be concluded that in the group with slight weight change, no significant alteration of serum insulin levels was noted, nor did this group show a clear alteration of the adaptive hyperinsulinism. The sub-group with marked weight gain during the follow-up period had showed, subsequent to extensive weight loss, a definite decline of serum insulin levels; during the subsequent weight increase the IRI levels ranged between the values before and after dietary therapy, i.e. the serum insulin levels were proportional to the extent of the alteration in weight. Similar findings were reported by us in earlier investigations [27]. The changes in blood glucose were more pronounced than those in serum IRI. It appears that the secretion kinetics were near normal in patients who maintained their weight reduction. After weight increase, the typical reaction characteristic of obesity was clearly demonstrable. These investigations do not permit a conclusion as to the origin of hyperinsulinism $[6,7,20,21,27,32,37,38]$. An increased 'resistance' may be of prime importance $[2,8,13,16,35]$.

In conclusion, our investigations reveal that weight change after dietary therapy influences primarily the blood sugar level, secondarily the serum insulin secretion. The level of serum cholesterol and triglycerides rose and this was little modified by the alteration of weight. It is suggested that blood lipids may primarily reflect the dietary intake.
It would be desirable to supplement these investigations with long-term studies, incorporating other methods of weight reduction (fasting, appetite suppressors, fat-increased diet).

\section{References}

1. Aretz, H.H., Liebermeister, H., Schulz, H., Probst, G.: Psychische Veränderungen bei Adipösen unter einer Reduktionsdiät. Dtsch. med. Wschr. 96, 778, (1971).

2. Berger, M., Gries, F.A., Herberg, L., Liebermeister, H.: Insulinempfindlichkeit des Glucosestoffwechsels und der Lipolyse im menschlichen Fettgewebe in vitro bei Adipositas mit und ohne Diabetes mellitus. Vortrag No 15, 5. Kongr. Dtsch. Diab. Ges. Bonn (1970).

3. Berkowitz, D.: Metabolic changes associated with obesity before and after weight reduction. J.A.M.A. 187, 399-403 (1964).

4. Boyns, D.R., Crossley, J.N., Abrams, M.E., Jarrett, R.J., Keen, H.: Oral glucose tolerance and related factors in a normal population sample. I. Blood sugar, plasma insulin, glyceride, and cholesterol measurements and the effects of age and sex. Brit. med. J. 1969 I, 595-598.

5. Caldwell, A.B., Watson, P., Green, D.B., Florin, A., Braun, P., Bierenbaum, M.L.: Weight reduction and serum cholesterol levels. Amer. J. clin. Nutr. 12, $401-405$ (1963).

6. Daweke, H.: Bestimmung der insulinähnlichen Aktivität im Blut des Menschen unter normalen und pathologischen Bedingungen. Habil-Schr. Düsseldorf (1964).

7. Daweke, H., von Landeghem, H., Bach, I., Zimmermann, H., Breitbach, A.: Bestimmung der insulinähnlichen Aktivität und der physiologischen Insulinreserve bei schwerer Adipositas. Klin. Wschr. 43, $185-190(1965)$.

8. Di Girolamo, M., Rudman, D. : Effect of weight reduction upon the sensitivity of rat adipose tissue to insulin. Fed. Proc. 25, 441 (1966).

9. Dole, V.P.: A relation between nonesterified fatty acids in plasma and the metabolism of glucose. J. clin. Invest. 35, 150-154 (1956).

10. Engelhardt, A., Jahnke, K., Pilger, H.: Ernährungsgewohnheiten Fettsüchtiger und Wege zu ihrer therapeutischen Beeinflussung. Med. Klin. 58, 1754-1759 (1963).

11. Farquhar, J.W., Frank, A., Gross, R.C., Reaven, G.M.: Glucose, insulin and triglyceride responses to high and low carbohydrate diets in man. J. clin. Invest. 45, 1648 (1969).

12. Farrant, P.C., Neville, R.W.J., Stewart, G.A.: Insulin release in response to oral glucose in obesity: The effect of reduction of body weight. Diabetologia 5 , 198 (1969).

13. Faulhaber, J.D., Petruzzi, E.N., Eble, H., Ditschuneit, H. : In-vitro Untersuchungen über den Fettstoffwechsel isolierter menschlicher Fettzellen in Abhängigkeit von der Zellgröße: Die durch Adrenalin induzierte Lipolyse. Horm. Metab. Res. 1, 80-86 (1969).

14. Galbraith, W.B., Connor, W.E., Stone, D. B.: Weight. loss and serum lipid changes in obese subjects given low calorie diets of varied cholesterol content. Ann. int. Med. 64, 268-275 (1966).

15. Gordon, E.S.: Nonesterified fatty acids in the blood of obese and lean subjects. Amer. J. clin. Nutr. 8, $740-745(1960)$.

16. Gries, F.A., Daweke, H., Liebermeister, H. : Diabetes mellitus bei Fettsucht. Verh. Dtsch. Ges. inn. Med. Vortr. No 5 Wiesbaden (1970). 
17. Hales, C.N., Randle, P.J.: Immunoassays of insulin with insulin-antibody precipitate. Biochem. J. 88, $137-146$ (1963).

18. Harrison, M.T., Harden, R.M.: The long term value of fasting in the treatment of obesity. Lancet $1966 \mathrm{II}$, $1340-1342$.

19. Irsigler, K., Waldhäusl, W.: Änderungen einzelner Parameter des Fett- und Kohlehydratstoffwechsels bei Adipösen durch Abmagerung. Wien. klin. Wschr. 81, 534-536 (1969).

20. Jackson, I.M.D., McKiddie, M.T., Buchanan, K.D.: Effect of fasting on glucose and insulin metabolism of obese patients. Lancet 1969 I, 285-288.

21. Karam, J.H., Grodsky, G.M., Forsham, P.H.: The relationship of obesity and growth hormone to serum insulin levels. Ann. N.Y. Acad. Sci. 131, 374-387 (1965).

22. Krall, L.P.: Treatment of early diabetes. In: Camerini-Davalos, R., H.S. Cole, Eds. : Early Diabetes Advances in Metabolic Disorders. Suppl. 1, p. 395399. Now York: Academic Press 1970.

23. Kreutz, F.H.: Enzymatische Glycerinbestimmung. Klin. Wschr. 40, 362-363 (1962).

24. Kreutz, F.H.: Enzymatic determination of glycerol in the measurement of triglycerides. Int. Congr. Clin. Chem. Detroit (1963).

25. Laube, H., Köhle, K., Ditschuneit, H., Pfeiffer, E.F.: Dauererfolge von Fastenkuren. Dtsch. med. Wschr. $\mathbf{9 7 ,} 830-835$ (1972).

26. Liebermeister, H., Probst, G., Jahnke, K.: Erfahrungen mit dem Appetithemmer Fenfluraminhydrochlorid bei der Adipositas. Med. Klin. 64, 2101-2107 (1969).

27. Liebermeister, H., Daweke, H., Gries, F.A., Schilling, W.H., Grüneklee, D., Probst, G., Jahnke, K.: Einfluß der Gewichtsredulation auf Metabolite des Kohlehydrat- und Fettstoffwechsels und auf das Verhalten des Seruminsulins bei Fettsucht. Diabetologia 4, $123-132(1968)$.

28. Liebermeister, H., Daweke, H., Jahnke, K., Grüneklee, D., Preiss, H., Oberdisse, K.: Influence d'un régime amaigrissant sur la tolérance au glucose et sur le taux sérique de l'insuline chez des obèses simples et chez les obèses diabétiques. Médicine et Nutrition 64, $21-29$ (1970).

29. Lindner, H., Müller, R., Rahn, U., Ritz, J.P., Tillmann, W.: Langzeitbeobachtung über den Wert von Fasten und Reduktionskost. Med. Klin. 65, 1914$1919(1970)$.

30. Lochner, W., Nasserie, M.: Untersuchung über den Herzstoffwechsel und die coronare Durchblutung insbesonders bei Dinitrophenolvergiftung. Pflügers Arch. ges. Physiol. 271, 405-419 (1960).
31. MeCuish, A.C., Munro, J.F., Duncan, L.J.P.: Followup study of refractory obesity treated by fasting. Brit. med. J. 1968 I, $91-92$.

32. Nikkilä, E.A., Taskinen, M.R. Insulin secretion rate at different blood glucose levels. Effect of obesity, fasting and hyperglyceridemia. Diabetologia 5, 49-50 abstr. (1969).

33. Ohlson, R.E.: Obesity as nutrition disorder. Fed. Proc. 18, 58 (1959).

34. Power, L., Collin, G., De L'Hortet, Conn, J.: The effect of frozen storage on serum insulin-like activity. Metabolism 15, 103-106 (1966).

35. Rabinowitz, D., Zierler, K.L. : Forearm metabolism in obesity and its response to intraarterial insulin. Characterization of insulin resistance and evidence for adaptive hyperinsulinism. J. clin. Invest. 41, 21732181 (1962).

36. Rudnick, P.A., Taylor, K.W.: Effect of prolonged carbohydrate restriction on serum insulin levels in mild diabetes. Brit. med. J. 1965 I $1225-1228$.

37. Samaan, N.J., Brown, R., Fraser, R., Trayner, I.: Effect of obesity and of starvation on insulin activity. Brit. med. J. 1965 I, $1153-1156$.

38. Salans, L.B., Knittle, J.L., Hirsch, J.: The role of adipose cell size and adipose tissue sensitivity in the carbohydrate intolerance of human obesity. J. clin. Invest. 47, 153-165 (1968).

39. Sailer, S., Sandhofer, F., Braunsteiner, H.: Overweight and triglyceride levels in normal persons and patients with diabetes mellitus. Metabolism 15, 135$137(1966 a)$.

40. Schettler, G.: Arteriosklerose. Stuttgart: Thieme Verlag 1963.

41. Schilling, W.H., Oberdisse, K., Hüter, K.A., Blank, H.: Vergleichende Untersuchungen mit der oralen und intravenösen Glucosebelastung zur Erfassung einer verminderten Kohlenhydrattoleranz. Diabetologia 1, $187-194(1966)$

42. Technicon Arbeitsvorschrift nach: Zlatkis, A., Zak, B., Boyle, A.J.: A new method for the direct determination of serum cholesterol. J. Lab. clin. Med. 41, $486-492(1953)$.

43. Voss, H.J.: Spätergebnisse der Diättherapie bei Fettsucht. Dissertation Düsseldorf 1967.

44. Williamson, J.R., Mellanby, J., Krebs, H.A.: Enzymic determination of D (-) $\beta^{\prime}$ hydroxybutyric acid and acetoacetic in blood. Biochem. J. 82, 90-96 (1962).

45. Wissenschaftliche Tabellen, Geigy, 7. Edition (1968).

Dr. R. Hewing

D-4723 Neubeckum

Beckumer Str. 94

Federal Republic of Germany 